\title{
Biodiversity beyond National Jurisdiction and the Limits of the Commons
}

Spatial and Functional Complexities

\author{
Joanna Mossop and Clive Schofield
}

\begin{abstract}
This paper addresses spatial and functional complexities relating to biodiversity beyond national jurisdiction against the context of negotiations towards an international legally binding instrument on its conservation and sustainable use. A number of uncertainties are highlighted in relation to the extent of the maritime zones of coastal States and therefore the spatial scope of the Commons. These uncertainties include instability in coasts and therefore baselines from which maritime claims are predominantly measured, particularly in an era of sea level rise; excessive maritime claims to baselines and from islands, maritime disputes and the incomplete delineation of continental shelf limits seawards of 200 nautical miles from the coast. The issues raised by horizontal and vertical ecological connectivity are also explored. Potential options to deal with these challenges are then discussed.
\end{abstract}

\section{Keywords}

Biodiversity - areas beyond national jurisdiction - commons - maritime claims baselines - maritime zones - sea level rise - maritime disputes - continental shelf limits - adjacency - connectivity - due regard

\section{$1 \quad$ Introduction}

As negotiations proceed for a new international legally binding instrument (ILBI) for the conservation and sustainable use of marine biodiversity in areas beyond national jurisdiction (BBNJ), it is becoming clear that a number of spatial and functional complexities exist that underpin and should inform 
the issues under discussion. ${ }^{1}$ This chapter addresses two particular challenges. First, what the geographic and material scope of the agreement is with respect to activities in areas beyond national jurisdiction $(\mathrm{ABNJ})$. This geographic definition, while seemingly straightforward, is in fact far from being so. This paper sets out some of the reasons why the spatial extent of ABNJ may be difficult to determine. Second, the vertical and horizontal ecological connectivity of the oceans means that management of activities in ABNJ without factoring in such connectivity will give rise to legal and practical issues in the future.

The continental shelf beyond 200 nautical miles $(\mathrm{M})$ provides particular challenges in creating a coherent legal framework for ABNJ. First, the fact that many of the proposed outer limits to continental shelf areas seawards of $200 \mathrm{M}$ have yet to be considered by the Commission on the Limits of the Continental Shelf (CLCS), leads to horizontal uncertainties in relation to the determination of the spatial scope of ABNJ. Maritime disputes and excessive maritime claims also serve to complicate the jurisdictional picture. Second, because the parts of the continental shelf that extend beyond the limits of the Eez lie beneath the high seas, vertical connectivity issues arise in the layering and interactions between the legal jurisdiction of the coastal State with the BBNJ framework, especially where ecosystems transcend the divide between areas within national jurisdiction (AWNJ) and ABNJ.

What emerges is a complex layering of overlapping maritime zones in the context of an ocean characterised by horizontal and vertical connectivity between activities, zones, layers and ecosystems. This chapter first sets out the spatial uncertainties that may impact the extent of the $A B N J$, including shifting baselines against the context of sea level rise, excessive maritime claims and disputes as well as issues concerning the delineation of the outer limits of the continental shelf. The chapter then considers what legal principles could be included in the ILBI to reflect horizontal and vertical connectivity. It also recommends that the ILBI include provisions that specifically respond to some of the complexities we have identified.

\section{Spatial Uncertainties}

As noted above the ILBI applies to activities in ABNJ. This begs the question, what are the limits of $\mathrm{ABNJ}$ ? $^{2}$ The answer to this question is, in turn, dependant

1 This chapter was written after the third session of the Intergovernmental Conference and refers to documents and negotiations up to that date.

2 This section of the paper is adapted from part of an earlier paper. For greater detail see, C.H. Schofield and L. Bernard, 'The Limits of the Commons', in Diamond, J. (ed.), Common 
on the limits of national jurisdiction. There are a number of reasons why uncertainty exists regarding the limits of national jurisdiction and therefore the spatial extent of ABNJ. These include issues related to: the instability of coastlines and therefore the baselines from which maritime claims are generally measured, especially in a period characterised by rising sea levels; the lack of certainty in the delineation of maritime limits as a result excessive maritime claims and maritime disputes; the slow progress in the delineation of the outer limits of the continental shelf seawards of $200 \mathrm{M} \mathrm{EEz} \mathrm{limits;} \mathrm{and} \mathrm{uncertainties}$ about entitlements to maritime zones generated by small and/or sparsely or uninhabited insular features.

\subsection{Changing Baselines}

The United Nations Convention on the Law of the Sea (LOSC) ${ }^{3}$ provides for zones of maritime jurisdiction with the outer limits of maritime zones being generally defined by distance measurements from baselines along the coast. In particular, the limits of the territorial sea, contiguous zone and exclusive economic zone (EEZ) are all defined by reference to distance measurements. That is, to maximum distances of $12 \mathrm{M}^{4}{ }_{24} \mathrm{M}^{5}$ and $200 \mathrm{M}^{6}$ respectively. ${ }^{7}$

Baselines are therefore fundamental to the delineation of the outer limits of national jurisdiction. More specifically, outer limits are generally constructed through the "envelope of arcs" method. ${ }^{8}$ Consequently, it is the most seaward, critical basepoints along the baseline that are essential to delineating outer limits to national jurisdiction rather than a coastal State's baseline as a whole.

Currents: Examining How We Govern Ocean Commons, (Leiden/Boston: Martinus Nijhoff/ Brill, 2020).

3 United Nations, United Nations Convention on the Law of the Sea, 1833 UnTS 3, opened for signature 10 December 1982, Montego Bay, Jamaica, entered into force 16 November 1994. Also available at: <http://www.un.org/Depts/los/convention_agreements/convention_overview_ convention.htm > [hereinafter 'LOSC' or 'the Convention'].

4 Ibid., arts. 3 and 4.

5 Ibid., art. 33 .

6 Ibid., art. 57 .

7 The delineation of the outer edge of the continental shelf where it exceeds a distance of $200 \mathrm{M}$ from baselines along the coast is a more complex task that does not rely on distance measurements from baselines alone (see below). Nonetheless, distance measurements from baselines, notably the 200 and $350 \mathrm{M}$ limits, remain essential to the delineation of outer continental shelf limits. LOSC, art. 76 .

8 C.M. Carleton and C.H. Schofield, 'Developments in the Technical Determination of Maritime Space: Charts, Datums, Baselines, Maritime Zones and Limits', 3(3) Maritime Briefing (Durham, International Boundaries Research Unit, 2001) at 62. 
The predominant type of baselines provided for under the LOSC are "normal" baselines that are coincident with "the low-water line along the coast as marked on large-scale charts officially recognized by the coastal State." ${ }^{\prime 2}$ These are what can be termed the coastal State's "default" baselines in that they do not require express declaration.

As normal baselines coincide with the low-water line along the coast, they are dependent on the stability of coasts. However, it has long been recognised that coasts are inherently dynamic land/sea features which can both advance offshore through deposition or accretion of material or, alternatively, retreat to landwards as a result of coastal inundation and erosion. Consequently, the traditional view has been that normal baselines can change location or "ambulate" over time..$^{10}$ It follows that if the basepoints from which the outer limits of maritime claims are measured alter in position, then the maritime jurisdictional limits measured from them will also change. ${ }^{11}$ Where the baseline advances the outer limits of the maritime claims measured from that baseline will expand seawards. Conversely, where the normal baseline recedes the coastal State may lose jurisdiction over maritime areas as the outer limits of their maritime zones are pulled back.

With respect to $A B N J$, changes in the extent of this area will only occur if the critical basepoints controlling the $200 \mathrm{M}$ limits of EEZ claims are impacted. In this context it is important to note that relatively few basepoints control $200 \mathrm{M}$ as compared, for example, with the number of basepoints required to generate $12 \mathrm{M}$ territorial sea limits.

Coastal and therefore normal baseline instability is, however, likely to be exacerbated by global sea level rise. ${ }^{12}$ This is particularly the case in light of

$9 \quad$ LOsc, art. 5 .

10 International Law Association, Report of the International Law Association Committee on International Law and Sea Level Rise (2019) <https://www.researchgate.net/publication/330938568_International_Law_and_Sea_Level_Rise_Report_of_the_International_ Law_Association_Committee_on_International_Law_and_Sea_Level_Rise> (accessed 26 November 2019). Also of note in this context is that the ILA Committee on Baselines under the International Law of the Sea concluded that normal baselines are ambulatory. See, C.G. Lathrop, J.A. Roach and D.R. Rothwell (eds), Baselines under the International Law of the Sea: Reports of the International Law Association Committee on Baselines under the International Law of the Sea, Brill Research Perspectives on the Law of the Sea, (Leiden/ Boston: Brill, 2019), at 58.

11 M.W. Reed, Shore and Sea Boundaries: The Development of International Maritime Boundary Principles through United States Practice, Volume 3 (Washington, DC, U.S. Department of Commerce, National Oceanic and Atmospheric Administration, 200o), p. 185 .

12 The Intergovernmental Panel on Climate Change (IPCC) in its Fifth Assessment Report $\left(\mathrm{AR}_{5}\right)$ of 2013 medium confidence-level projection is for global mean sea level rise of 
the anticipated pace and scale of sea level rise as well as evidence that the rate of sea level rise is accelerating. Consequently, contractions in the scope of $\mathrm{AWNJ}$, and corresponding increases in the scope of $\mathrm{ABNJ}$, cannot be ruled out. Indeed, the Intergovernmental Panel on Climate Change (IPCC) found in its 2019 "Special Report on the Ocean and Cryosphere in a Changing Climate" that global mean sea level rise in the period 2006-2015 has been two and a half times the rate for the period 1901-1990, a rate of sea level rise stated with high confidence to be "unprecedented over the last century."13 The counterpoint to this is that there are emerging efforts on the part of some States to fix maritime baselines, limits and boundaries in order to circumvent the contraction of national claims to maritime jurisdiction and thereby also to fix the extent of ABNJ. ${ }^{14}$ These developments suggest that some progressive interpretation of the baseline provisions of the LOSC is underway.

\subsection{Excessive Baseline Claims}

It can also be observed that many coastal States consider all or part of their coastlines to be geographically complex enough to create systems of straight baselines. Article 7(1) of the LOSC provides that straight baselines should only be applied in localities "where the coastline is deeply indented and cut into, or if there is a fringe of islands along the coast in its immediate vicinity." Article 7 of the LOsC thus allows States to depart from the application of the normal baseline and measure maritime jurisdictional zones from straight baselines drawn along selected parts of their coastlines. ${ }^{15}$ However, this exception to the

0.52-0.98 under its representative concentration pathways (RCP) 8.5 scenario which envisages continued very high greenhouse gas emissions and a resulting increase in global mean temperature likely to exceed $2^{\circ} \mathrm{C}$. See, Intergovernmental Panel on Climate Change (IPCC), 'Climate Change 2013: The Physical Science Basis', Contribution of Working Group I, Fifth Assessment Report of the Intergovernmental Panel on Climate Change (Cambridge, and New York, Cambridge University Press, 2013), at 1139-1140, available online: <http:// www.climatechange2o13.org/images/report/WG1AR5_ALL_FINAL.pdf>.

13 IPCC, 'Special Report on the Ocean and Cryosphere in a Changing Climate', approved at its 5 1st Session held from 20-23 September 2019, available on the IPCC website at $<$ https://www.ipcc.ch/srocc/home/>.

14 Notably on the part of Pacific Islands States. See, D. Freestone and C.H. Schofield, 'Islands Awash Amidst Rising Seas?: Sea Level Rise and Insular Status under the Law of the Sea', 34 International Journal of Marine and Coastal Law, 2019, 391, at 404-408; and, D. Freestone and C.H. Schofield, 'Republic of the Marshall Islands - 2016 Maritime Zones Declaration Act: Drawing lines in the sea', 31 International Journal of Marine and Coastal Law, 2016, 720. See also R. Frost et al., 'Redrawing the map of the Pacific', 95 Marine Policy, 2018, 302. See J.R.V. Prescott and C.H. Schofield, The Maritime Political Boundaries of the World, (2 ed., Martinus Nijhoff, 2005), at 137-166. 
general rule of normal baselines along the coast was intended to deal with particularly complex coastal geography where the configuration of the coastline is such that using "highly irregular"16 normal baselines would result in similarly irregular maritime limits. ${ }^{17}$

Unfortunately, Article 7 of the LOSC provides no objective tests by which to ascertain whether a particular stretch of coastline is deeply enough or frequently enough indented to warrant the application of straight baselines or, alternatively, whether a fringe of islands is numerous enough or close enough to the coast to justify the use of straight baselines. ${ }^{18}$

Consequently, many States have interpreted Article 7 in a very flexible and arguably excessive manner which serves not only to capture or enclose overly large marine spaces as internal waters and simultaneously advance the coastal State's starting point for measuring its maritime claims. ${ }^{19}$ Of note here is that the ICJ, in its decision in the Qatar/Bahrain Case, stated unequivocally that the method of straight baselines in accordance with Article 7 of LosC "must be applied restrictively". ${ }^{20}$ Moreover, any system of straight baselines or other types of straight line baseline ${ }^{21}$ still needs to be connected back to the low-water line. ${ }^{22}$ Indeed, the United Nations Group of Technical Experts on Baselines concluded that a "straight baseline system must be closed" such that, "whether the baselines are drawn along the coast of an island or of the mainland, the system must start and finish on or above the low water line" and that where

16 International Hydrographic Organization (гно) and the International Association of Geodesy (IAG) Manual on Technical Aspects of the Law of the Sea (TALOs Manual), Special Publication No.51, (Monaco: International Hydrographic Bureau, 2014), chapters 4 and 6.

17 United Nations, Baselines: An Examination of the Relevant Provisions of the United Nations Convention on the Law of the Sea, (New York: Office for Ocean Affairs and the Law of the Sea, United Nations, 1989).

18 While the United States has published its own guidelines on the proper application of Article 7, these guidelines are not binding on other States. See, United States Department of State, 'Developing Standard Guidelines for Evaluating Straight Baselines', Limits in the Seas, No.1o6, (Washington D.C.: Bureau of Oceans and International Environmental and Scientific Affairs, 31 August 1987). See also, J.A. Roach and R.W. Smith, 'Straight Baselines: The Need for a Universally Applied Norm', 31 International Journal of Marine and Coastal Law, 2000, 47; International Law Association, Baselines under the International Law of the Sea: Final Report (2018).

19 See Prescott and Schofield, supra n 15, 139-166.

20 Case Concerning Maritime Delimitation and Territorial Questions Between Qatar and Bahrain (Qatar/Bahrain), Merits, Judgment (2001) ICJ Reports 40, 103.

21 Such as river or bay closing lines or archipelagic baselines. See, LosC, arts. 9, 10 and 47 respectively.

22 See also Anglo-Norwegian Fisheries Case (United Kingdom v. Norway), Order, [1951] ICJ 117, at $128-129$. 
straight baselines were drawn connecting a fringe of islands, "all the intermediate basepoints must be located on or above the low water line."23 As a result, straight line types of baselines are not immune to changing location of normal baselines.

Where excessive baseline claims are made, uncertainty is added to the true scope of the ABNJ. However, unless such apparently excessive baseline claims are challenged by other States, there is a risk that the outer limits of maritime claims delineated from them may end up defining the spatial extent of $\mathrm{ABNJ}$ by default. ${ }^{24}$

\subsection{Incomplete Delineation of Outer Continental Shelf Limits}

The LOSC provides coastal States with sovereign rights over the EEZ out to a distance of $200 \mathrm{M}$ from the coast, beyond which lie the high seas. ${ }^{25}$ These rights relate to both the water column and the underlying seabed and subsoil, regardless of whether the continental margin actually extends that distance offshore, unless overlapping claims with neighbouring States exist. ${ }^{26}$

Where coastal States are positioned on broad continental margins, however, they are able to assert rights over those parts of the continental shelf beyond the $200 \mathrm{M} \mathrm{EEZ} \mathrm{limit} \mathrm{forming} \mathrm{part} \mathrm{of} \mathrm{their} \mathrm{natural} \mathrm{prolongation.} \mathrm{These} \mathrm{areas} \mathrm{of}$ continental shelf beyond the $200 \mathrm{M}$ limit are sometimes referred to as the 'outer' or 'extended' continental shelf and are overlain by parts of the high seas. ${ }^{27}$ Beyond the outer limits to the continental shelf, the deep seabed is referred to as "the Area"; exploration and exploitation of the mineral resources of the Area is under the jurisdiction of the International Seabed Authority (ISA). ${ }^{28}$

23 See United Nations, Baselines, supra n 18, at 23.

24 It can be observed, however, that many excessive baseline claims are subject to international protest, especially on the part of the United States through its Freedom of Navigation (FON) program. These protests are made to ensure that the United States maintains maritime mobility and to prevent the United States from acquiescing or tacitly accepting legal positions with which it disagrees. See, J.A. Roach and R.W. Smith, Excessive Maritime Claims, (3 ed., Leiden/Boston: Martinus Nijhoff Publishers, 2012), at 6-9 and $72-130$.

25 LOSC, arts. $5^{6-57,76(1)}$ and 86.

26 The coastal State's rights over the continental shelf within $200 \mathrm{M}$ of the coast are, however, governed in accordance with Part vi (dealing with the continental shelf) of the Convention rather than Part v (dealing with the EEZ).

27 Losc, art. 76(1). It can be observed that neither of the terms 'outer' or 'extended' continental shelf appears in the LOSC or is generally accepted - indeed tribunals have emphasised that the continental shelf is a single entity rather than an 'inner' and 'outer' shelf. Barbados $v$ Trinidad and Tobago, Award (2006) XXVII RIAA 147, para. 213. LOSC, Part XI. See also the ISA's website at <https://www.isa.org.jm/>. 
Article 76 of the LOSC goes on to lay down a complex series of formulae through which the coastal State can establish its rights to the outer edge of its continental shelf areas seaward of the $200 \mathrm{M}$ limit. Essentially, article 76 provides two formulae according to which coastal States can establishment existence of a continental margin beyond the $200 \mathrm{M} \mathrm{limit,}{ }^{29}$ together with two maximum constraints or 'cut-off' lines. ${ }^{30}$

To establish the outer limits of the continental shelf beyond $200 \mathrm{M}$, coastal States need to make a submission of information to the Commission on the Limits of the Continental Shelf (CLCS), ${ }^{31}$ a body established under the LOSC comprised of technical experts. In order to make these calculations, and thus establish entitlement to outer continental shelf areas in accordance with Article 76 , a coastal State is required to gather information related to the morphology of its continental margin and its geological characteristics as well as bathymetric information relating to water depth. Additionally, geodetically robust distance measurements are necessary to determine, for example, the location of $200 \mathrm{M}$ and $350 \mathrm{M}$ limit lines. Although complex, the fundamental point here is that Article 76 of LOSC, through the CLCs, delivers a definable outer limit to the continental shelf claims of coastal States - something that has been referred to as "the real achievement" of Article 76 of the LOSC. ${ }^{32}$

The CLCS will consider all the information and other material submitted by coastal States in proposing the outer limits of their continental shelf beyond 200 M. ${ }^{33}$ The CLCS, however, lacks the mandate to consider any submission in which a land or maritime dispute exists, ${ }^{34}$ unless prior consent has been given by the States that are parties to such a dispute. ${ }^{35}$ Since these submissions cannot be considered by the CLCS, the coastal States involved are precluded from delineating the outer limits of their continental shelf beyond $200 \mathrm{M}$ with certainty.

29 The two entitlement formulae are the 'Gardiner Line', based on reference to depth or thickness of sedimentary rocks overlying the continental crust, or the 'Hedberg Line' consisting of 6o M from the foot of the continental slope. See, LOSC, art. 76 (4)(a)(i and ii). Either a distance of $350 \mathrm{M}$ from relevant baselines or $100 \mathrm{M}$ from the 2,500 metre depth isobath. See, LOSC, art. 76(5).

31 Losc, art. $76(8)$.

32 See T. McDorman, 'The Role of the Commission on the Limits of the Continental Shelf: A technical body in a political world', 17 International Journal of Marine and Coastal Law, 2002, 301-324, at 307 .

33 LOsC, Annex II, Art. 3.

34 Rules of Procedure of the Commission on the Limits of the Continental Shelf, CLCs /40/ Rev.1, 17 April 2008, Annex I, Art. 5(a).

Ibid. 
The existence of overlapping maritime claims, including to areas of continental shelf seawards of $200 \mathrm{M}$, therefore creates uncertainty over the location of the $A W N J / A B N J$ divide and thus ambiguity over the scope of ABNJ. A further source of doubt over the spatial extent of ABNJ is caused by the fact that the CLCs has a very substantial backlog of submissions to address. At the time of writing submissions to the CLCS encompassed in excess of $37 \mathrm{~km}^{2}$ million, ${ }^{36}$ with less than one third of the 84 full submissions made to the CLCs having received recommendations from the Commission. ${ }^{37}$

\section{$2.4 \quad$ Excessive Claims from Islands}

A further type of excessive maritime claims that can impact on the extent of ABNJ concerns claims to EEZ and continental shelf rights from insular features which may, in fact, be more appropriately categorised as "rocks" within the meaning of article 121(3) of the LOSC, which therefore "shall have no exclusive economic zone or continental shelf." ${ }^{38}$ In general, coastal States have tended to advance broad maritime claims from often small, remote and uninhabited insular features. Such expansive maritime claims based on seemingly insignificant islands have been difficult to critique with conviction in light of the ambiguity in article 121(3) that the term "rock" only applies to islands "which cannot sustain human habitation or an economic life of their own."39

The first international judicial interpretation of article 121(3) featured in the arbitral award in the 2016 case brought by the Philippines against China under

36 Robert van de Poll, personal communication.

37 For a list of all submissions and recommendations, see the CLCS website at $<\mathrm{http}$ ://www. un.org/Depts/los/clcs_new/clcs_home.htm>.

38 LOSC, art. 121(3).

39 Ibid. The interpretation of Article 121 has led to substantial scholarly debate among law of the sea scholars. See, for example, J.I. Charney, 'Rocks that cannot sustain human habitation', American Journal of International Law, 93, 4 (1999): 863-78; A.G. Oude Elferink, 'Clarifying Article 121 (3) of the Law of the Sea Convention: The limits set by the nature of international legal processes', Boundary and Security Bulletin, Vol.6, no.2 (Summer 1998): 58-68.; B. Kwaitkowska and A.H.A. Soons, 'Entitlement to maritime areas of rocks which cannot sustain human habitation or economic life of their own', Netherlands Yearbook of International Law, XXI (1990): 139-81; Prescott and Schofield, supra n 19, at 73-79; J.M. Van Dyke, J. Morgan and J. Gurish, 'The exclusive economic zone of the northwestern Hawaiian Islands: when do uninhabited islands generate an EEZ?', San Diego Law Review, 25, 3 (1988): 425-494; and J.M. Van Dyke and R.A. Brooks, 'Uninhabited islands: their impact on the ownership of the oceans' resources', Ocean Development International Law Journal, 12 (1983): 265-84. 
the LOSC. ${ }^{40}$ In its Award, the Tribunal set a high bar for island to generate EEZ and continental shelf rights. In particular, the Tribunal ruled that:

- the assessment of a feature should be based on its "natural capacity" to sustain human habitation "without external additions or modifications intended to increase its capacity" to do so;

- "[t]he mere presence of a small number of persons on a feature does not constitute permanent or habitual residence there and does not equate to habitation"; ${ }^{42}$ and

- the capacity of an insular feature to generate EEZ rights depends on capacity to sustain either "a stable community of people" 43 or economic activity that "must be oriented around the feature itself and not focused solely on the waters or seabed of the surrounding territorial sea" and not dependent on outside resources or purely extractive in nature are capable of generating extended maritime claims. ${ }^{44}$

In establishing this high standard for fully entitled islands the Tribunal referred to the history of the Convention to reach the conclusion that Article 121(3) was included in the Convention as a "counterpoint" to the introduction of the EEZ, serving to prevent the expansion in maritime rights provided by the EEZ "from going too far" by disabling tiny features from:

unfairly and inequitably generating enormous entitlements to maritime space that would serve not to benefit the local population, but to award windfall to the (potentially distant) State to have maintained a claim to such a feature. ${ }^{45}$

Of particular note for the present discussion, on the basis of the travaux préparatoires, the Tribunal determined that Article 121(3) is a "provision of limitation" with:

40 In the Matter of the South China Sea Arbitration before an Arbitral Tribunal Constituted under Annex VII to the 1982 United Nations Convention on the Law of the Sea between the Republic of the Philippines and the People's Republic of China, Award, 12 July 2016, Permanent Court of Arbitration (PCA), PCA Case No. 2013-19, available at, <https://pcacpa.org, at https://pcacases.com/web/view/7> (hereinafter, the South China Sea Award). It should be noted that the second author of this Chapter served as an independent expert witness in this case.

41 Ibid., para. 541.

42 Ibid., para. 489 .

43 Ibid., para. 542.

44 Ibid., para. 543 .

45 Ibid., para. 516. 
the object and purpose of preventing encroachment on the international seabed reserved for the common heritage of mankind and of avoiding the inequitable distribution of maritime spaces under national jurisdiction. ${ }^{46}$

This ruling is clearly at odds with the aforementioned maximalist tendency in State practice towards claiming continental shelf and EEZ rights from small, remote and sparsely or uninhabited features which tends to substantially reduce the spatial extent of ABNJ. Following the ruling, questions have been raised about the implications for other small features from which large maritime claims have been made. ${ }^{47}$ These uncertainties are likely to give rise to questions about which areas of ocean are subject to coastal State jurisdiction, or to the ILBI.

\section{Functional Connectivities and Complexities}

A growing body of scientific research is demonstrating the ecological connectivity of the oceans. It is now clear that areas within AWNJ and ABNJ are ecologically linked in multiple ways which can be both active and passive in character. ${ }^{48}$ Active connectivity involves self-propulsion by the species involved, for instance the long-distance migrations of sea birds, sea turtles, sharks and marine fish such as tuna. In contrast, passive connectivity is predominantly driven by ocean currents. Both active and passive modes of connectivity transcend AWNJ and ABNJ.

Ecological connectivity is not in itself a problem, but the ocean is divided for legal purposes into jurisdictional zones in which there are different legal principles, and states have different rights and responsibilities. Challenges arise where activities in one area have an impact on marine ecosystems that straddle multiple legal zones, limits and boundaries. This limits the ability to

\footnotetext{
$46 \quad$ Ibid., para. 535 .

47 For example see, 'Regime of Islands in the Aftermath of the South China Sea Arbitration' 112 Proceedings of the 112th Annual Meeting, American Society of International Law, 2018, 3.

48 E. Popova, et al., 'Ecological Connectivity between the Areas beyond National Jurisdiction and Coastal Waters: Safeguarding Interests of Coastal Communities in Developing Countries' 104 Marine Policy, 2019, 9o; D.C. Dunn, et al., 'Adjacency: How legal precedent, ecological connectivity, and Traditional Knowledge inform our understanding of proximity', Policy brief, Nereus Program (2017). https://nereusprogram.org/reports/ policy-brief-adjacency-how-legal-precedent-ecological-connectivity-and-traditionalknowledge-inform-our-understanding-of-proximity/ (accessed 12 July 2019).
} 
manage activities coherently, something that the First Global Integrated Marine Assessment indicated was necessary to improve the ocean environment. ${ }^{49}$

\subsection{Horizontal Connectivity}

Horizontal interaction or connectivity issues can occur when species migrate through more than one maritime zone. Coastal States will have jurisdiction over such species when they are in their EEZ or territorial sea, but beyond the EEZ the freedom of high seas applies, and the species may or may not be subject to fishing regulated by a Regional Fisheries Management Organisation (RFMO). The LOSC contains obligations on States to cooperate in the case of straddling or highly migratory fish species, although this was considered to be insufficient to respond to the practical problems in achieving cooperation. ${ }^{50}$ The UN Fish Stocks Agreement (UNFSA) ${ }^{51}$ was negotiated to resolve some of the coordination difficulties arising from managing fish stocks in such a situation. However, the challenges in conserving and sustainably using marine biodiversity go well beyond a single sector. Migratory species can be impacted by a wide range of other activities including shipping, deep seabed mining, and pollution, among others. Other horizontal connectivity problems arise from the fact that a vulnerable or important marine ecosystem may be dependent on juvenile replenishment from another ocean feature that could be in a different maritime zone. Efforts to protect the ecosystem, for example by establishing MPAs, may be undermined if the connected areas are not also protected. ${ }^{52}$ Hence there is an effort to create a framework in the ILBI for networks of marine protected areas in $\mathrm{ABNJ}$.

Some coastal States have emphasised the problems they see arising for areas within their jurisdiction if activities on the high seas are not regulated effectively. For example, Pacific Small Island Developing States (PSIDS) have intervened repeatedly during the PrepCom and IG C s, pointing out the dependence

49 Summary of the first global integrated marine assessment (22 July 2015) UN Doc A/70/112, para. 40; R.D. Long, A. Charles and R.L. Stephenson, 'Key Principles of Marine Ecosystembased Management', 57 Marine Policy, 2015, 53.

$50 \quad$ Losc, arts. 63, 64, and 116. See, e.g., E. Meltzer, 'Global Overview of Straddling and Highly Migratory Fish Stocks: The Nonsustainable Nature of High Seas Fisheries', 25 Ocean Development and International Law, 1994, 255 .

51 United Nations Agreement for the Implementation of the Provisions of the United Nations Convention on the Law of the Sea of 10 December 1982 relating to the Conservation and Management of Straddling Fish Stocks and Highly Migratory Fish Stocks, 34 ILM 1542 (1995); 2167 UNTS 88.

$5^{2}$ See, for example, K.I. Pendoley et al., 'Protected Species Use of a Coastal Marine Migratory Corridor Connecting Marine Protected Areas' 161 Marine Biology, 2014, 1455. 
that they have on migratory species that travel through the high seas and their coastal waters. Small island, but often "large ocean", developing States are particularly dependent on the health of the oceans not only in terms of access to marine resources for food security, but also in economic terms as a critical source of revenue and to support livelihoods as well as in cultural terms. ${ }^{53}$ For example, the value accruing to Pacific Islands Forum Fisheries Agency (FFA) members ${ }^{54}$ from the tuna species, which migrate far beyond national jurisdictional limits, in 2018 has been estimated at US $\$ 3.05$ billion, ${ }^{55}$ making it the dominant development opportunity and source of government revenue for many of these States. ${ }^{56}$

In contrast, other coastal States have expressed concern that measures taken on the high seas not impede their rights to explore and exploit the resources of AWNJ. During the negotiations there has, for example, been resistance to the idea that the provisions on environmental impact assessment (EIA) for activities in ABNJ might affect the process for EIA for activities in AWNJ - despite the fact that an obligation to undertake EIA s in AWNJ exists in both customary international law and article 206 of the LOSC. Similarly, coastal States are keen to ensure that the presence of an MPA in adjacent areas of the high seas would not undermine their rights in their EEZ.

\subsection{Vertical Connectivity}

Vertical connectivity is a particularly complex problem in the BBNJ context. Within national jurisdiction, coastal States have jurisdiction over many activities that impact marine biodiversity, especially fisheries and the exploitation of non-living resources. Up to $200 \mathrm{M} \mathrm{EEZ} \mathrm{limits} \mathrm{coastal} \mathrm{States} \mathrm{can} \mathrm{generally}$ exercise control over the impacts on marine biodiversity from activities within their EEZ and continental shelf. Beyond $200 \mathrm{M}$, if a coastal State has an outer or extended continental shelf, the regime of the high seas applies to the superjacent water column. Article 77(1) of the LOSC provides that coastal States have

53 J.E. Hay, 'Small Island Developing States: Coastal Systems, Global Change and Sustainability', 8 Sustainability Science, 2013, 309, at 318.

54 Pacific forum Fisheries Agency Members comprise: Australia, the Cook Islands, the Federated States of Micronesia, Fiji, Kiribati, the Marshall Islands, Nauru, New Zealand, Niue, Palau, Papua New Guinea, Samoa, the Solomon Islands, Tokelau, Tonga, Tuvalu and Vanuatu.

55 Forum Fisheries Agency and the Pacific Community (2019) Value of WCPFC-CA Tuna Fisheries 2019.

$5^{6} \quad$ For example, it has been estimated that revenues derived from tuna species accounted for over 6o per cent of the public budget for Kiribati in 2012. See, World Bank, Pacific Possible: Tuna Fisheries Report, (Washington DC, World Bank, 2017). 
sovereign rights over the continental shelf for the purpose of exploring and exploiting its resources. These include the:

living organisms belonging to sedentary species, that is to say, organisms which, at the harvestable stage, either are immobile on or under the seabed or are unable to move except in constant physical contact with the seabed or subsoil..$^{57}$

Complex questions arise in the context of ввNJ as to how the definition of sedentary species will apply to the collection of marine genetic resources (MGRS) at or near the seabed above a State's continental shelf that lies under high seas. ${ }^{58}$ Vertical connectivity problems arise because ecosystems found in places such as hydrothermal vents and seamounts do not fall neatly into categories of sedentary or non-sedentary species. For example, the microbes at hydrothermal vents can be found in the seabed, circulating in the water column or in symbiosis with other creatures including tube worms. ${ }^{59}$ The problem in applying the sedentary species definition to MG Rs has received limited attention in the ввNJ discussions, despite the fact that most delegations now accept that a single legal framework should apply to MGR $s$ in the high seas and Area. ${ }^{60}$

In addition to having sole rights to exploit the resources of the seabed, coastal States also have a range of obligations in relation to the preservation of the marine environment. Environmental impacts on benthic ecosystems can arise from activities conducted under the jurisdiction of the coastal State (such as mining or fishing for sedentary species) as well as from activities under the high seas regime (such as bottom fishing and dumping from vessels). One issue that has not received much attention is the fact that, because activities on the continental shelf beyond $200 \mathrm{M}$ are essentially conducted in and adjacent to the high seas, all such activities are inherently undertaken in a transboundary context. Customary international environmental law principles including the

57 LOSC, art. 77(4).

$5^{8}$ See e.g., C.H. Allen, 'Protecting the Oceanic Gardens of Eden: International Law Issues in Deep-Sea Vent Resource Conservation and Management', 13 Georgetown International Environmental Law Review, 2000, 563; J. Mossop, 'The Relationship between the Continental Shelf Regime and a New International Instrument for Protecting Marine Biodiversity in Areas beyond National Jurisdiction', 75 ICES Journal of Marine Science, 2018, 444.

$59 \quad$ Allen, supra n 58 , at 627.

6 J. Mossop, 'Towards a Practical Approach to Regulating Marine Genetic Resources' 8 ESIL Reflections, 2019, https://esil-sedi.eu/esil-reflection-towards-a-practical-approach-toregulating-marine-genetic-resources/ (accessed 22 November 2019). 
obligation to prevent significant harm to commons areas and the obligation to conduct environmental impact assessments ${ }^{61}$ are particularly relevant for activities in proximity to a continental shelf. ${ }^{62}$

\subsection{Coastal State Interests, Adjacency, and the IL BI Negotiations}

As discussed, coastal States have two interests in relation to the extended continental shelf: a need to ensure that they can exercise their sovereign rights to explore and exploit the living and non-living resources of the shelf; and a responsibility to protect and preserve the marine environment in the vicinity of the continental shelf and beyond.

These connectivity problems have led to an argument by some that coastal States should have a greater level of influence in relation to measures to protect the marine environment in areas of the high seas adjacent to their maritime zones. A group of authors have argued in a policy brief that coastal States seeking to ensure protection of marine biodiversity in adjacent ABNJ areas should be given special responsibilities due to ecological connectivity. ${ }^{63}$ The Policy Brief states:

... so long as adjacent States can prove that their management measures conserve marine biodiversity within or beyond their national jurisdiction, the over-arching conservation mandate of UNCLOS would support granting to those States greater influence over management of those ABNJ resources to which they lie adjacent. Under this approach, those qualified adjacent States would be allocated the primary responsibility to coordinate with existing sectoral and regional organizations to become the leading architects of new regional conservation agreements. ${ }^{64}$

This Policy Brief, as well as interventions along similar lines by small island developing States in the Preparatory Committee, has created a debate about the appropriate legal principles that apply to the intersection between coastal States rights and duties, and those applicable in ABNJ. In the President's "Aid to Negotiations" issued prior to the second meeting of the intergovernmental

61 Legality of the Threat or Use of Nuclear Weapons, Advisory Opinion, [1996] ICJ Reports 266, para. 148; Responsibilities and Obligations of States Sponsoring Persons and Entities with Respect to Activities in the Area, Advisory Opinion [2011] ITLOS Rep 10, paras. 116 and 148.

62 J. Mossop, The Continental Shelf beyond 200 Nautical Miles: Rights and Responsibilities (Oxford University Press, 2016) p. 106.

63 Dunn et al., supra $\mathrm{n} 48$.

64 Ibid.at 5 . 
conference (IGC2), a long list of possible general principles and approaches were included, based on contributions made during IGC1. ${ }^{65}$ At the very end of the list was option (v), "take into account adjacency". ${ }^{66}$ Adjacency was also included as an option for principles in the substantive parts including MGRS, area-based management tools (АВMT s) and EIA s. One difficulty was that there was no clear explanation of what "adjacency" meant, meaning that many delegates assumed that the goal was to give additional rights or responsibilities to coastal States in adjacent areas of the high seas. This did not receive enthusiastic endorsement by many delegations in the IGC.

The use of adjacency changed in the draft text issued by the President prior to $\mathrm{IGC}_{3}{ }^{67}$ Adjacency no longer appeared in a section on general principles and approaches, nor as a principle or approach under the separate parts. Instead, references to "adjacent coastal States" featured in specific aspects of the draft text.

Key mentions of coastal State interests in the draft text included the following:

- The introductory segment included a statement that the rights of coastal States "shall be respected in accordance with the Convention". 68

- Where MGRs from ABNJ are also found in AWNJ, activities with respect to those resources shall be conducted with "due regard" for the rights and legitimate interests of any coastal State under the jurisdiction of which such resources are found. 69

- If MGRS are accessed in ABNJ that may result in utilisation of MGR S in AWNJ, either prior consent or prior notification and consultation with the coastal State is required. ${ }^{70}$

- For Aвмтs, measures adopted under the ILbi should not "undermine the effectiveness of measures adopted by coastal States in adjacent areas within national jurisdiction and shall have due regard for the rights, duties and

65 For discussion of the different principles raised in the Preparatory Committee, see A. Oude Elferink, 'Coastal States and MPAs in ABNJ: Ensuring Consistency with the LOSC', 33 International Journal of Marine and Coastal Law, 2018, 437, at 439.

66 United Nations, President's Aid to Negotiations (3 December 2018) UN Doc A/Conf.232/ $2019 / 1^{*}$ at 8 .

67 United Nations, Draft text of an agreement under the United Nations Convention on the Law of the Sea on the conservation and sustainable use of marine biological diversity of areas beyond national jurisdiction (17 May 2019) UN Doc A/CONF.232/2019/6 (hereinafter 'draft text').

68 Draft text, art. 4(2).

69 Draft text, art. 9(2).

70 Draft text, art. 10(5). 
legitimate interests of all States". Consultations would be required with coastal States. ${ }^{71}$

- Where an АВMT is established in ABNJ but that area subsequently falls under the jurisdiction of the coastal State, the Авм must be amended. ${ }^{72}$

- Proposals for Авмт s must outline the impact on coastal States and any consultations with them. ${ }^{73}$ In addition, coastal States will be among the parties included in consultations under the ILBI processes. ${ }^{74}$

- EIAs should take into account possible impacts on transboundary areas including adjacent coastal States. ${ }^{75}$

- Adjacent coastal States should be included in consultation on EIAs. ${ }^{76}$

Not all of these proposals received support in the discussions at $\mathrm{IGC}_{3}$, but it is possible to make a few observations. First, the idea of adjacency proposed by the Policy Brief does not appear to have prevailed in the draft text. One attempt to partially revive this concept can be seen by a PSIDs proposal that the views and comments of coastal States should be given particular regard if an AвMT affects high seas pockets surrounded by AWNJ. ${ }^{77}$ Second, States are clearly beginning to work through the consequences for coastal States in some circumstances. However, many of the issues identified above are either not addressed, or addressed inadequately. Third, there is still a lack of clarity about the general legal principle that should govern the interaction between coastal States' rights and the rights of other States.

Potential Options

\subsection{Use of Principles}

Although the draft text appears to be moving towards setting out specific references to coastal States in respect of elements of the treaty, it is still likely to be important for the ILBI to set out general principles on how the relationship between areas under coastal State jurisdiction and ABNJ will be managed. Not every scenario can be covered with specific provisions.

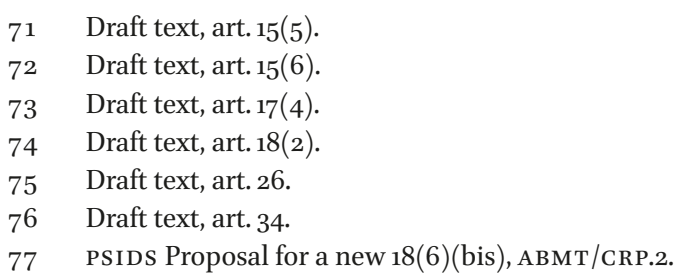


"Due regard" is often considered an organising principle of the LOsc. However, the LOSC does not generally require "due regard" for coastal States when considering the intersection between rights on the high seas and for coastal States. Article 87 provides that the freedoms of the high seas must be exercised by all States with due regard for the interests of other States in their exercise of high seas freedoms and for the rights with respect to activities in the Area, but does not mention coastal States. The freedom of fishing is "subject to the rights and duties as well as the interests of coastal States regarding straddling and highly migratory stocks". ${ }^{78}$ Article $78(2)$ requires coastal States not to infringe or unjustifiably interfere with the rights and freedoms of other States when exercising their rights over the continental shelf. ${ }^{79}$ The clearest example of the LOSC requiring due regard when exercising rights in ABNJ towards a coastal State is in article 142(1), which requires activities in the Area with respect to transboundary deposits to be undertaken with due regard to the rights and legitimate interests of any coastal State across whose jurisdiction such deposits lie.

Arguably, "due regard" is the appropriate general principle that should be applied in the ввNJ context. ${ }^{80}$ Some authors have suggested that it has general applicability to the intersection of rights in the LOsc. For example, Oxman argued that due regard is an organising principle in the law of the sea generally. ${ }^{81}$ Treves has suggested that due regard reflects:

a broader customary law rule necessarily implied in the need to ensure coexistence between the customary freedoms of the high seas, the rights in the Area and the rights of coastal States in the EEZ and on the continental shelf. ${ }^{82}$

78 LOsC, art. 116.

79 This has been equated with "due regard". See Chagos Marine Protected Area (Mauritius v. United Kingdom), Award, (2015) XXXI RIAA 359, para. 540. For a contrasting view see Mossop (2016), supra n 62, at 186.

8o Oude Elferink, supra $\mathrm{n}$ 65, at 447. The argument is further explored in Joanna Mossop and Clive Schofield, 'Adjacency and due regard: The role of coastal States in the BBNJ Treaty', Marine Policy, 2020, https://doi.org/10.1016/j.marpol.2020.103877.

81 B.H. Oxman, 'The Principle of Due Regard' in ITLOs, The Contribution of the International Tribunal for the Law of the Sea to the Rule of Law 1996-2016, (Leiden, Brill/Nijhoff, 2018) p. 108, at 112 .

82 T. Treves, " "Due regard" Obligations under the 1982 UN Convention on the Law of the Sea: The Laying of Cables and Activities in the Area', 34 International Journal of Marine and Coastal Law, 2019, 167, at 182. 
Although "due regard" appears open-ended and somewhat vague, judicial interpretation has given some content to the concept, albeit in bilateral examples of due regard. The International Tribunal on the Law of the Sea (ITLOS) in the Bay of Bengal case was of the view that where two States owe due regard to one another, discharge of the obligation may involve the conclusion of specific agreements or the establishment of cooperative arrangements. ${ }^{83}$ In the Chagos MPA arbitration, the Tribunal found that the conduct necessary to fulfil due regard obligations in article $56(2)$ will depend on the rights held, their importance, the extent of the anticipated impairment, the nature and importance of the proposed activities and the availability of alternative approaches. Consultation will normally be required with the rights-holding State. ${ }^{84}$ However, despite these judicial statements, there are aspects of the relationship between States that the ILBI will need to more explicitly elucidated rather than rely on a general principle. ${ }^{85}$

The formulation in draft article 4(2) does not apply due regard. Instead, the "rights and jurisdiction of coastal States ... shall be respected." One reading of this drafting is to give preference to coastal State rights over interests in ABNJ. In cases where the coastal States' rights might be intruded upon, respecting those rights might imply a limitation on the actions that can be taken in ABNJ. This would be an unnecessary and undesirable move away from the balancing approach represented by a due regard obligation.

\subsection{Managing Spatial and Functional Complexities in Practice}

We argue that specific provision can be made in the ILBI to deal with some of the issues identified earlier in this chapter.

\subsubsection{Uncertain Boundaries}

First, there is the question how to provide for uncertainties over maritime limits and boundaries, notably the outer limits of the continental shelf. In many cases, the law of the sea has provided for such uncertainties - for example, by indicating that States should make "every effort to enter provisional arrangements of a practical nature" pending an agreement on EEZ or continental shelf boundaries. ${ }^{86}$ In the context of the ILBI, a number of draft provisions call for consultations or notifications for adjacent coastal States. As explained,

83 Delimitation of the Maritime Boundary between Bangladesh and Myanmar in the Bay of Bengal (Bangladesh/Myanmar), Judgment, [2012] ITLOs Reports 4, para. 476.

84 Chagos MPA, supra $\mathrm{n} 79$, para. 519.

85 Oude Elferink, supra $n$ 65, at 465 .

86 LOsC, arts. 74(3) and 83(3). 
there are different reasons why it may be difficult to identify the coastal State. It could be decided, for example, that where a State has submitted information about the delineation of the outer limits of the continental shelf, but no recommendation has been received by the CLCS, that the outer limits provisionally identified by the coastal State be treated as the interim boundary between its jurisdiction and ABNJ. Where there is an overlapping claim where more than one State claims entitlement to a part of a continental shelf, the combined submissions could be used to determine the interim outer limits.

In relation to identifying which State is the coastal State that should be consulted, an assumption could be built into the ILBI that both (or all) claimant States are deemed the coastal State for the purposes of consultation. This may prove politically sensitive, but it must be remembered that under a principle of due regard, one coastal State's opposition to a proposal in ABNJ would not override other interests.

The issue with identifying the coastal State for the purpose of the exploitation of MGR s close to the continental shelf beyond $200 \mathrm{M}$ is much more complicated. The need for provisions dealing with uncertainty over the identity of the coastal State will depend in part on the content of the rights allocated to coastal States under the ILBI. For example, in draft article 10(5), a coastal State may have the right to consent to exploitation of MGRs that are found both in AWNJ and ABNJ. While the prospect of this option making it into the final ILBI is remote, this sort of provision makes the identity of the coastal State quite important. If there are any monetary benefits to be derived for coastal States, a more creative form of dealing with the dispute would have to be devised such as a trust arrangement until claims are settled.

\subsubsection{The Continental Shelf and ABNJ}

In light of the problems raised about applying the definition of sedentary species to MGRs, in an ideal world the ILBI would define what this means and how it will apply. One option might be to seek to redefine the concept of "sedentary species" for an MGR regime. This might involve stating that coastal State rights to living resources do not apply to MGRs, which would create a more coherent legal framework. Another option could involve giving expanded rights to the coastal State to MGRs found in seabed ecosystems in return for additional responsibilities for environmental protection. ${ }^{87}$ However, it must be acknowledged that both of these options will be politically hard to achieve. Unfortunately, it is highly likely that this issue will not be resolved in the ILBI.

87 Some possibilities are explored in Mossop (2018), supra $\mathrm{n}_{5} 8$. 
However, there may be scope for the issue to be taken up in the future by the Conference of the Parties.

Another issue is whether there should be a requirement for compatibility between measures adopted in the high seas and under national jurisdiction. Oude Elferink has argued persuasively that such a concept is unlikely to be accepted on the basis that there is no reason to expect this would lead to better environmental outcomes. ${ }^{88}$

As in any negotiation towards an international treaty, not all potential issues can be resolved in the final treaty text. This may be because there is an irreconcilable difference of opinion, leading to deliberate ambiguity or omission from the text altogether. In the case of the ILBI, there is significant time pressure on the negotiations, with the General Assembly only authorising four meetings in Resolution 72/249. This does not mean that there may not be more sessions of the IGC, only that the process of extending the conference is not clear at the time of writing. Therefore, States have been keen to try to conclude the treaty by the fourth session. If this is the case, then the finer details of how the rights of coastal States will intersect with the ILBI may be considered expendable. This is especially true since there is considerable debate about the core elements of the treaty.

Nevertheless, at a bare minimum, the ILBI would be well-served if States agreed on the use of the principle of due regard to govern the relationship with coastal States, rather than an approach of "respecting" coastal State rights. The latter formulation leans too far in the direction of coastal State interests overriding interests in the high seas to be consistent with the LOsC.

This paper has highlighted a number of spatial and functional complexities and uncertainties. Unfortunately, the zonal approach to managing ocean activities arguably has many disadvantages and tends to inhibit the adoption of sound ecosystem-based management across large ocean spaces, notwithstanding some laudable efforts towards transboundary cooperation in ocean governance. It would be helpful if the ILB I could assist in avoiding ambiguities at the intersection of ABNJ and AWNJ. However, if this is not possible, it is potentially a matter that could be addressed through dispute settlement under the ILBI. 
Joanna Mossop and Clive Schofield - 9789004422438

Downloaded from Brill.com06/08/2021 11:11:01PM via Victoria University of Wellington 